\title{
Body Composition in Severe Infantile Malnutrition*
}

\author{
J. S. Garrow, $\dagger$ K. Fletcher, and D. Halliday \\ (From the Medical Research Council, Tropical Metabolism Research Unit, University of the \\ West Indies, Jamaica)
}

In Jamaica infantile malnutrition is most serious among children about 1 year old. The clinical picture may be of the marasmic or the kwashiorkor type, and intermediate forms often occur (1). Waterlow (2) suggested that the essential result of malnutrition was to produce protein depletion in the child, and many attempts have been made to measure the extent of this depletion. Chemical analysis of biopsy samples of liver, muscle, and skin (3-5) and measurement by isotope dilution techniques of total body water (6) and total exchangeable potassium (7) in malnourished children have indicated that there is a decrease in total protein and potassium and an increase in water, particularly extracellular water. The effect on body composition of a low protein diet has been carefully studied in the rat (8-13) and in the pig (14). Waterlow, Cravioto, and Stephen (15) have reviewed the available evidence from human and animal studies and have postulated a body composition for a normal, a malnourished, and a treated child aged 1 year. However, we are not aware of a whole body analysis of any child, normal or malnourished, between birth and $4 \frac{1}{2}$ years of age.

We have been very fortunate in obtaining, through the co-operation of the Department of Anatomy of the University of the West Indies, the bodies of nine children between the ages of 6 and 16 months. Five of these children died from malnutrition, and the other four were relatively well nourished. We have, therefore, been able to examine the changes in body composition produced by malnutrition in human infants.

\footnotetext{
* Submitted for publication August 25, 1964 ; accepted November 19, 1964.

† Address requests for reprints to: Dr. J. S. Garrow, Tropical Metabolism Research Unit, University College of the West Indies, Mona, St. Andrew, Jamaica, British West Indies.
}

\section{Methods}

\section{Clinical material}

The nine children have been arranged on clinical grounds into five classes. The criteria defining these classes and some general data concerning the children are given in Table $I$. The children in classes $A$ and $B$ had no edema, those in classes $\mathrm{C}$ and $\mathrm{E}$ had gross edema involving all four limbs and the trunk, and those in class $\mathrm{D}$ had edema of the lower limbs only. The birth weight of E.W., S.D., and C.B. was not known, but they were said to be full-term babies of average size, and a birth weight of $3.4 \mathrm{~kg}$ has been assumed. The "expected weight for age" is derived from the 50th percentile figures for American children (16). This weight has been increased or decreased by the amount by which the birth weight differs from $3.4 \mathrm{~kg}$. The expected weight for height is obtained by plotting weight against height for boys and girls on the 50th percentile, and from the line thus obtained deriving an expected weight for a given height.

A summary of the clinical histories of these children is given in Appendix I.

\section{Dissection technique}

At post-mortem examination, after small pieces had been removed for histology, the brain and the liver were put into covered weighed containers, and all the other viscera with any free fluids were put into a third covered weighed container. These three fractions were then weighed and analyzed, and a correction was made for those parts taken for histology. The remainder of the body was divided sagittally, and the two halves were weighed. One half only was analyzed, and it was assumed that the composition of the other half was similar. The greatest difference in weight between the two halves was $2 \%$ of the total weight. The leg of each of the eight bodies hydrolyzed in alkali was divided through the knee joint, and the lower leg was analyzed separately to see if its composition reflected that of the remainder of the body. In the case of the body hydrolyzed in acid, the skin and subcutaneous tissues were removed from the muscle and bone, and these were analyzed as separate fractions.

Losses during dissection. These losses were probably small except in the case of S.D. from whom about 400 $\mathrm{ml}$ of fluid was lost when the body was opened. For purposes of calculation it has been assumed that this fluid contained $4 \mathrm{~g}$ of protein and $0.4 \mathrm{mEq}$ of potassium 
TABLE I

Nutritional status of subjects

\begin{tabular}{|c|c|c|c|c|c|c|c|c|c|}
\hline \multirow{2}{*}{$\begin{array}{l}\text { Clinical class } \\
\text { Child }\end{array}$} & \multicolumn{2}{|c|}{$\mathrm{A}^{*}$} & \multicolumn{2}{|c|}{ B } & \multicolumn{2}{|c|}{ C } & \multicolumn{2}{|c|}{ D } & \multirow{2}{*}{$\begin{array}{c}\mathrm{E} \\
\text { C.A. }\end{array}$} \\
\hline & L.S. & C.w.w. & R.H. & E.W. & c.w. & S.D. & C.B. & A.C. & \\
\hline $\begin{array}{l}\text { Sex } \\
\text { Age, mos } \\
\text { Weight before post-mortem, } \mathrm{kg} \\
\text { Height, } \mathrm{cm} \\
\text { Severity of edema }\end{array}$ & $\begin{array}{l}M \\
10 \\
4.69 \\
57 \\
-\end{array}$ & $\begin{array}{l}\mathrm{F} \\
14 \\
4.17 \\
58 \\
-\end{array}$ & $\begin{array}{l}F \\
9 \\
7.50 \\
65 \\
-\end{array}$ & $\begin{array}{l}\mathrm{F} \\
13 \\
7.70 \\
71 \\
-\end{array}$ & $\begin{array}{l}F \\
6 \\
4.10 \\
55 \\
++\end{array}$ & $\begin{array}{l}F \\
16 \\
6.70 \\
65 \\
++\end{array}$ & $\begin{array}{l}\text { F } \\
14 \\
5.67 \\
67 \\
+\end{array}$ & $\begin{array}{l}M \\
12 \\
6.30 \\
70 \\
+\end{array}$ & $\begin{array}{l}M \\
11 \\
7.60 \\
70 \\
++\end{array}$ \\
\hline $\begin{array}{l}\text { Birth weight, } \mathrm{kg} \\
\text { Expected weight for age, } \ddagger \mathrm{kg} \\
\text { Expected weight for height, } \mathrm{kg} \\
\text { Weight as } \% \text { expected for age } \\
\text { Weight as \% expected for height }\end{array}$ & $\begin{array}{c}3.1 \\
9.75 \\
4.65 \\
48 \\
101\end{array}$ & $\begin{array}{l}1.6 \\
8.85 \\
5.25 \\
47 \\
79\end{array}$ & $\begin{array}{c}4.3 \\
9.61 \\
7.15 \\
78 \\
105\end{array}$ & $\begin{array}{l}(3.4) \dagger \\
10.30 \\
9.05 \\
75 \\
85\end{array}$ & $\begin{array}{l}3.4 \\
7.26 \\
4.42 \\
57 \\
93\end{array}$ & $\begin{array}{l}(3.4) \dagger \\
10.66 \\
7.15 \\
63 \\
94\end{array}$ & $\begin{array}{l}(3.4) \dagger \\
10.25 \\
7.75 \\
55 \\
73\end{array}$ & $\begin{array}{l}3.4 \\
9.75 \\
8.70 \\
65 \\
73\end{array}$ & $\begin{array}{l}2.9 \\
10.25 \\
8.70 \\
74 \\
87\end{array}$ \\
\hline $\begin{array}{l}\text { Body fat as } \% \text { body weight } \\
\text { Liver fat as } \% \text { liver weight } \\
\text { Liver fat as \% body fat }\end{array}$ & $\begin{array}{r}22.5 \\
2.4 \\
0.4\end{array}$ & $\begin{array}{r}19.2 \\
3.7 \\
0.8\end{array}$ & $\begin{array}{r}25.5 \\
17.9 \\
2.7\end{array}$ & $\begin{array}{r}18.4 \\
7.6 \\
1.9\end{array}$ & $\begin{array}{r}4.6 \\
27.0 \\
36.5\end{array}$ & $\begin{array}{l}3.9 \\
6.0 \\
6.5\end{array}$ & $\begin{array}{l}16.0 \\
50.1 \\
30.2\end{array}$ & $\begin{array}{l}15.4 \\
43.7 \\
39.6\end{array}$ & $\begin{array}{r}20.0 \\
39.0 \\
9.1\end{array}$ \\
\hline
\end{tabular}

* Class A : clinically well nourished and with normal liver fat; class B : clinically well nourished but with increased liver fat; class C: marasmic kwashiorkor with gross edema, dyspigmentation, and loss of subcutaneous fat; class D: kwashiorkor with gross fatty liver,"dyspigmentation," "and edema; class E: malnutrition plus proteinuria.

$\dagger$ Assumed birth weight.

$\ddagger$ Corrected for birth weight.

per $100 \mathrm{ml}$. Apart from this case, it is assumed that the difference between the sum of the wet weights of the parts after dissection and the weight of the body before dissection is due to evaporative loss, and for the calculation of total body water this weight of water loss has been added.

\section{Analytical techniques}

Alkaline hydrolysis. The various parts of the eight bodies shown in Table III were hydrolyzed in alkali. They were heated in a volume of $2 \mathrm{~N} \mathrm{NaOH}$ equal to four times the wet weight of the part until the soft tissues were dissolved. The bone mineral was separated and measured as described elsewhere (17). Samples of the solution were taken for estimation of protein, fat, and potassium.

Protein was calculated from total nitrogen $\times 6.25$; the nitrogen was determined by a micro-Kjeldahl method. It was found that under the conditions of alkaline hydrolysis used there was a loss of $16 \%$ of the total nitrogen, so the figure obtained for nitrogen in the hydrolysate was multiplied by $100 / 84$ to calculate total nitrogen.

Fatty acids were extracted from an acidified sample of the hydrolysate with petroleum ether (bp, 62 to 82 ) or, in the case of the brain hydrolysate, with a $1: 3$ mixture of methanol and chloroform. This was separated and evaporated to dryness, and the fatty acid residue was weighed.

TABLE II

Percentage body composition at various ages found by whole body analysis; interpolated values for child of 1 year

\begin{tabular}{|c|c|c|c|c|c|c|c|c|c|c|c|}
\hline \multirow[b]{2}{*}{ Subject } & \multicolumn{3}{|c|}{ Fetus } & \multirow{2}{*}{$\underset{1 \mathrm{yr}}{\operatorname{Infant}}$} & \multirow{2}{*}{$\begin{array}{l}\text { Child } \\
4 \frac{1}{2} \text { yrs }\end{array}$} & \multicolumn{6}{|c|}{ Adult } \\
\hline & $1,500 \mathrm{~g}$ & $2,500 \mathrm{~g}$ & $3,500 \mathrm{~g}$ & & & 25 yrs & 35 yrs & 42 yrs & $46 \mathrm{yrs}$ & 48 yrs & $60 \mathrm{yrs}$ \\
\hline Authority* & (3) & (3) & (3) & Interpolated & (2) & (2) & (1) & (2) & $(4,6)$ & (5) & $(5,6)$ \\
\hline $\begin{array}{l}\text { Fat as } \% \text { body wt } \\
\text { Protein, } \mathrm{g} / \mathrm{kg} \text { fat- }\end{array}$ & 3.5 & 7.6 & 16.2 & 20.0 & 22.7 & 14.9 & 12.5 & 23.6 & 19.4 & 4.3 & 27.9 \\
\hline free body wt & 111 & 126 & 137 & 170 & 238 & 195 & 165 & 192 & 234 & 206 & 238 \\
\hline Water, $\mathrm{g} / \mathbf{k g}$ ffbw & 856 & 837 & 822 & 780 & 697 & 728 & 775 & 733 & 674 & 730 & 704 \\
\hline $\mathrm{Na}, \mathrm{mEq} / \mathrm{kg}$ ffbw & 105 & 101 & 97.0 & 95.0 & 99.9 & 92.3 & & 96.5 & 82.6 & & 78.2 \\
\hline $\mathrm{K}, \mathrm{mEq} / \mathrm{kg}$ ffbw & 49.6 & 52.1 & 50.8 & 58.0 & 65.0 & 71.5 & & 73.0 & 66.5 & & 66.6 \\
\hline $\mathrm{Ca}, \mathrm{mEq} / \mathrm{kg} \mathrm{ffbw}$ & 354 & 413 & 464 & 698 & 1,050 & 1,070 & 912 & 1,240 & & 1,030 & 1,070 \\
\hline $\mathrm{Mg}, \mathrm{mEq} / \mathrm{kg} \mathrm{ffbw}$ & 19.7 & 20.4 & 20.6 & 24.7 & 29.6 & 39.5 & & 35.4 & & 38.7 & 40.3 \\
\hline$P, \mathrm{~mm} / \mathrm{kg}$ ffbw & 126 & 152 & 171 & 226 & 338 & 452 & 284 & 417 & & 358 & 365 \\
\hline
\end{tabular}

* 1. Mitchell, H. H., T. S. Hamilton, F. R. Steggerda, and H. W. Bean. J. biol. Chem. 1945, $158,625$.

2. Widdowson, E. M., R. A. McCance, and C. Spray. Clin. Sci. 1951, 10, 113.

3. Widdowson, E. M., and C. Spray. Arch. Dis. Childh. 1951, 26, 205.

4. Forbes, R. M., A. R. Cooper, and H. H. Mitchell. J. biol. Chem. 1953, 203, 359

5. Forbes, R. M., H. H. Mitchell, and A. R. Cooper. J. biol. Chem. 1956, 223, 969

6. Forbes, G. B., and A. M. Lewis. J. clin. Invest. 1956, 35, 596. 
TABLE II

Body composition of eight children by alkaline hydrolysis

\begin{tabular}{|c|c|c|c|c|c|c|c|c|c|c|c|c|c|}
\hline & & \multicolumn{2}{|c|}{ Brain } & \multicolumn{2}{|c|}{ Liver } & \multicolumn{2}{|c|}{ Other viscera } & \multicolumn{2}{|c|}{ Lower leg } & \multicolumn{2}{|c|}{ Remainder } & \multicolumn{2}{|c|}{ Total } \\
\hline \multirow{8}{*}{$\begin{array}{l}\text { L.S. } \\
\text { Weight, } 4.69 \mathrm{~kg} \\
\text { Loss, } 0.19 \mathrm{~kg}\end{array}$} & & $g$ & $\%$ & $\boldsymbol{g}$ & $\%$ & $\boldsymbol{g}$ & $\%$ & $\boldsymbol{g}$ & $\%$ & 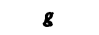 & $\%$ & g & $\%$ \\
\hline & Wet weight & 760.0 & 100.0 & 165.0 & 100.0 & 502.0 & 100.0 & 167.7 & 100.0 & $2,908.0$ & 100.0 & $4,502.7$ & 100.0 \\
\hline & Protein & 97.7 & 12.9 & 38.1 & 23.1 & 81.8 & 16.3 & 29.1 & 17.3 & 438.5 & 15.1 & 685.2 & 15.2 \\
\hline & Fat & 31.9 & 4.2 & 3.9 & 2.4 & 16.7 & 3.3 & 54.7 & 32.0 & 945.0 & 32.5 & $1,052.2$ & 23.4 \\
\hline & Bone mineral & & & & & & & 2.4 & 1.9 & 88.6 & 3.0 & 91.0 & 2.0 \\
\hline & Water & 624.2 & 82.1 & 121.8 & 73.8 & 399.5 & 79.6 & 80.7 & 48.3 & $1,421.7$ & 48.9 & $2,647.9$ & 58.8 \\
\hline & Soluble mineral & 6.2 & 0.8 & 1.2 & 0.7 & 4.0 & 0.8 & 0.8 & 0.5 & 14.2 & 0.5 & 26.4 & 0.6 \\
\hline & Potassium, $m E q$ & 103.5 & $139.5 *$ & 5.86 & $35.5^{*}$ & 23.0 & $45.8^{*}$ & 2.6 & $16.1 *$ & 93.8 & $32.2 *$ & 228.7 & $50.8^{*}$ \\
\hline \multirow{7}{*}{$\begin{array}{l}\text { C.W.W. } \\
\text { Weight, } 4.17 \mathrm{~kg} \\
\text { Loss, } 0.14 \mathrm{~kg}\end{array}$} & Wet weight & 762.4 & 100.0 & 185.0 & 100.0 & 549.0 & 100.0 & 149.0 & 100.0 & $2,386.2$ & 100.0 & $4,033.2$ & 100.0 \\
\hline & Protein & 72.3 & 9.5 & 27.0 & 14.8 & 86.5 & 15.8 & 20.1 & 13.5 & 358.2 & 15.0 & 564.1 & 14.0 \\
\hline & Fat & 37.7 & 4.9 & 6.6 & 3.7 & 9.5 & 1.7 & 57.2 & 38.2 & 688.8 & 28.9 & 799.8 & 19.8 \\
\hline & Bone mineral & & & & & & & 1.8 & 1.2 & 74.4 & 3.1 & 76.2 & 1.9 \\
\hline & Water & 645.9 & 84.8 & 149.9 & 80.7 & 448.5 & 81.7 & 70.0 & 46.6 & $1,252.3$ & 52.5 & $2,566.6$ & 63.6 \\
\hline & Soluble mineral & 6.5 & 0.8 & 1.5 & 0.8 & 4.5 & 0.8 & 0.7 & 0.5 & 12.5 & 0.5 & 25.7 & 0.6 \\
\hline & Potassium, $m E q$ & 84.4 & $110.8 *$ & 10.2 & $55.2 *$ & 41.1 & $74.9 *$ & 2.6 & $17.9 *$ & 69.6 & $29.2 *$ & 207.9 & $51.6 *$ \\
\hline \multirow{7}{*}{$\begin{array}{l}\text { R.H. } \\
\text { Weight, } 7.50 \mathrm{~kg} \\
\text { Loss, } 0.69 \mathrm{~kg}\end{array}$} & Wet weight & 780.0 & 100.0 & 292.0 & 100.0 & 913.0 & 100.0 & 268.0 & 100.0 & $4,558.0$ & 100.0 & $6,811.0$ & 100.0 \\
\hline & Protein & 77.0 & 9.8 & 32.6 & 11.2 & 98.5 & 10.8 & 30.0 & 11.2 & 563.0 & 12.4 & 801.1 & 11.8 \\
\hline & Fat & 56.9 & 7.3 & 52.3 & 17.9 & 23.3 & 2.6 & 99.2 & 37.0 & $1,684.9$ & 37.0 & $1,916.6$ & 28.2 \\
\hline & Bone mineral & & & & & & & 5.1 & 1.9 & 142.9 & 3.1 & 148.0 & 2.2 \\
\hline & Water & 639.7 & 82.1 & 205.0 & 70.2 & 783.4 & 85.7 & 132.4 & 49.4 & $2,145.7$ & 47.0 & $3,906.2$ & 57.2 \\
\hline & Soluble mineral & 6.4 & 0.8 & 2.1 & 0.7 & 7.8 & 0.9 & 1.3 & 0.5 & 21.5 & 0.5 & 39.1 & 0.6 \\
\hline & Potassium, $m E q$ & 70.1 & $90.0 *$ & 15.7 & $53.7 *$ & 42.9 & $47.0 *$ & 6.0 & $22.4^{*}$ & 128.5 & $28.2 *$ & 265.2 & $38.1 *$ \\
\hline \multirow{7}{*}{$\begin{array}{l}\text { E.W. } \\
\text { Weight, } 7.70 \mathrm{~kg} \\
\text { Loss, } 0.48 \mathrm{~kg}\end{array}$} & Wet weight & 954.0 & 100.0 & 360.0 & 100.0 & 833.0 & 100.0 & 323.2 & 100.0 & $4,751.0$ & 100.0 & $7,221.2$ & 100.0 \\
\hline & Protein & 89.6 & 9.4 & $\mathbf{5 8 . 0}$ & 16.1 & 111.8 & 13.4 & 47.3 & 14.6 & 734.0 & 15.5 & $1,040.7$ & 14.4 \\
\hline & Fat & 46.7 & 4.9 & 27.3 & 7.6 & 36.0 & 4.3 & 99.3 & 30.7 & $1,206.0$ & 25.4 & $1,415.3$ & 19.6 \\
\hline & Bone mineral & & & & & & & 6.1 & 1.9 & 183.7 & 3.8 & 189.8 & 2.7 \\
\hline & Water & 809.5 & 84.9 & 272.0 & 75.5 & 678.4 & 81.5 & 168.8 & 52.3 & $2,601.3$ & 54.8 & $4,530.0$ & 62.7 \\
\hline & Soluble mineral & 8.2 & 0.8 & 2.7 & 0.8 & 6.8 & 0.8 & 1.7 & 0.5 & 26.0 & 0.5 & 45.4 & 0.6 \\
\hline & Potassium, $m E q$ & 71.7 & $75.1 *$ & 15.0 & 41.6* & 40.6 & $48.6 *$ & 6.7 & $20.6 *$ & 119.7 & $25.2 *$ & 253.7 & $35.1 *$ \\
\hline \multirow{7}{*}{$\begin{array}{l}\text { C.W. } \\
\text { Weight, } 4.10 \mathrm{~kg} \\
\text { Loss, } 0.28 \mathrm{~kg}\end{array}$} & Wet weight & 616.0 & 100.0 & 256.0 & 100.0 & 328.3 & 100.0 & 168.2 & 100.0 & $2,456.2$ & 100.0 & $3,824.7$ & 100.0 \\
\hline & Protein & 50.3 & 8.1 & 29.1 & 11.4 & 54.5 & 16.6 & 21.8 & 12.9 & 329.5 & 13.4 & 485.3 & 12.7 \\
\hline & Fat & 22.7 & 3.7 & 69.1 & 27.0 & 0 & 0 & 16.4 & 9.8 & 81.1 & 3.3 & 189.3 & 4.9 \\
\hline & Bone mineral & & & & & & & 2.1 & 1.2 & 71.5 & 2.9 & 73.6 & 2.0 \\
\hline & Water & 537.6 & 87.3 & 156.2 & 61.0 & 271.1 & 82.6 & 126.6 & 75.3 & $1,954.4$ & 79.6 & $3,045.9$ & 79.6 \\
\hline & Soluble mineral & 5.3 & 0.9 & 1.6 & 0.6 & 2.7 & 0.8 & 1.3 & 0.8 & 19.7 & 0.8 & 30.6 & 0.8 \\
\hline & Potassium, $m E q$ & & & & & & & & & & & 155.0 & $40.5 *$ \\
\hline \multirow{7}{*}{$\begin{array}{l}\text { S.D. } \\
\text { Weight, } 6.70 \mathrm{~kg} \\
\text { Loss, } 1.06 \mathrm{~kg} \dagger\end{array}$} & Wet weight & 688.0 & 100.0 & 278.0 & 100.0 & 593.0 & 100.0 & 302.5 & 100.0 & $3,777.5$ & 100.0 & $5,639.0$ & 100.0 \\
\hline & Protein & 53.9 & 7.8 & 39.4 & 14.2 & 84.2 & 14.3 & 31.1 & 10.2 & 480.0 & 12.7 & 688.6 & 12.2 \\
\hline & Fat & 27.4 & 4.0 & 16.7 & 6.0 & 13.1 & 2.2 & 25.6 & 8.5 & 175.0 & 4.6 & 257.8 & 4.6 \\
\hline & Bone mineral & & & & & & & 5.5 & 1.8 & 121.0 & 3.2 & 126.5 & 2.2 \\
\hline & Water & 600.7 & 87.3 & 219.7 & 79.0 & 490.8 & 82.7 & 237.9 & 78.7 & $2,971.8$ & 78.7 & $4,520.9$ & 80.2 \\
\hline & Soluble mineral & 6.0 & 0.9 & 2.2 & 0.8 & 4.9 & 0.8 & 2.4 & 0.8 & 29.7 & 0.8 & 45.2 & 0.8 \\
\hline & Potassium, $m E_{Q}$ & & & & & & & & & & & 200.0 & $35.6 *$ \\
\hline \multirow{7}{*}{$\begin{array}{l}\text { C.B. } \\
\text { Weight, } 5.67 \mathrm{~kg} \\
\text { Loss, } 0.11 \mathrm{~kg}\end{array}$} & Wet weight & 741.0 & 100.0 & 550.0 & 100.0 & 450.0 & 100.0 & 251.0 & 100.0 & $3,566.0$ & 100.0 & $5,558.0$ & 100.0 \\
\hline & Protein & 67.2 & 9.1 & 34.9 & 6.3 & 66.4 & 14.7 & 30.5 & 12.1 & 460.5 & 12.9 & 659.5 & 11.9 \\
\hline & Fat & 44.1 & 6.0 & 275.5 & 50.1 & 12.9 & 2.9 & 25.9 & 10.3 & 551.9 & 15.5 & 910.3 & 16.4 \\
\hline & Bone mineral & & & & & & & 3.8 & 1.5 & 129.8 & 3.6 & 133.6 & 2.4 \\
\hline & Water & 623.5 & 84.1 & 237.2 & 43.2 & 367.0 & 81.6 & 188.9 & 75.3 & $2,399.7$ & 67.3 & $3,816.3$ & 68.6 \\
\hline & Soluble mineral & 6.2 & 0.8 & 2.4 & 0.4 & 3.7 & 0.8 & 1.9 & 0.8 & 24.1 & 0.7 & 38.2 & 0.7 \\
\hline & Potassium, $m E q$ & 25.7 & $34.7 *$ & 15.3 & 28.4* & 18.7 & $53.5 *$ & 2.8 & $11.4^{*}$ & 85.0 & $24.0 *$ & 148.1 & $26.6 *$ \\
\hline & Wet weight & 746.0 & 100.0 & 355.0 & 100.0 & 811.2 & 100.0 & 326.0 & 100.0 & $4,726.0$ & 100.0 & $6,964.2$ & 100.0 \\
\hline & Protein & 59.0 & 7.9 & 22.3 & 6.3 & 69.3 & 8.5 & 27.5 & 8.5 & 491.5 & 10.4 & 669.5 & 9.6 \\
\hline & Fat & 46.2 & 6.2 & 138.5 & 39.0 & 23.7 & 2.9 & 93.7 & 28.8 & $1,217.3$ & 25.8 & $1,519.4$ & 21.8 \\
\hline Weight, $7.60 \mathrm{~kg}$ & Bone mineral & & & & & & & 4.1 & 1.3 & 104.5 & 2.2 & 108.6 & 1.6 \\
\hline Loss, $0.64 \mathrm{~kg}$ & Water & 634.5 & 85.0 & 192.3 & 54.2 & 711.1 & 87.7 & 198.7 & 60.8 & $2,883.8$ & 61.0 & $4,620.5$ & 66.3 \\
\hline & Soluble mineral & 6.3 & 0.9 & 1.9 & 0.5 & 7.1 & 0.9 & 2.0 & 0.6 & 28.9 & 0.6 & 46.2 & 0.7 \\
\hline & Potassium, $m E q$ & & & & & & & & & & & 165.0 & $23.7 *$ \\
\hline
\end{tabular}


TABLE IV

Body composition of one child by acid hydrolysis

\begin{tabular}{|c|c|c|c|c|c|c|c|c|c|c|c|c|}
\hline \multirow[t]{2}{*}{$\begin{array}{l}\text { A.C. } \\
\text { Weight, } 6.30 \mathrm{~kg} \\
\text { Loss, } 0.27 \mathrm{~kg}\end{array}$} & \multicolumn{2}{|c|}{ Brain } & \multicolumn{2}{|c|}{ Liver } & \multicolumn{2}{|c|}{ Other viscera } & \multicolumn{2}{|c|}{ Skin } & \multicolumn{2}{|c|}{ Remainder } & \multicolumn{2}{|c|}{ Total } \\
\hline & $\begin{array}{c}g \\
681.0\end{array}$ & $\begin{array}{c}\% \\
100.0\end{array}$ & $\begin{array}{c}g \\
880.0\end{array}$ & $\begin{array}{c}\% \\
100.0\end{array}$ & $\begin{array}{c}g \\
560.0\end{array}$ & $\begin{array}{c}\% \\
100.0\end{array}$ & $\begin{array}{c}g \\
1,527.0\end{array}$ & $\begin{array}{c}\% \\
100.0\end{array}$ & $\begin{array}{c}g \\
2,385.0\end{array}$ & $\begin{array}{c}\% \\
100.0\end{array}$ & $\begin{array}{c}g \\
6,033.0\end{array}$ & $\begin{array}{c}\% \\
100.0\end{array}$ \\
\hline Noncollagen protein & 48.2 & 7.1 & 55.9 & 6.4 & 42.8 & 7.6 & 42.9 & 2.8 & 167.9 & 7.0 & 357.7 & 5.9 \\
\hline Collagen & 0.3 & & 4.5 & 0.5 & 17.6 & 3.1 & 101.8 & 6.7 & 207.1 & 8.7 & 331.3 & 5.5 \\
\hline Fat & 30.2 & 4.5 & 385.0 & 43.7 & 13.2 & 2.4 & 352.0 & 23.0 & 193.0 & 8.1 & 973.4 & 16.2 \\
\hline Ash & 7.6 & 1.1 & 6.7 & 0.8 & 6.7 & 1.2 & 10.5 & 0.7 & 162.2 & 6.8 & 193.7 & 3.2 \\
\hline Water & 594.7 & 87.3 & 427.9 & 48.6 & 479.7 & 85.7 & $1,019.8$ & 66.8 & $1,654.8$ & 69.4 & $4,176.9$ & 69.2 \\
\hline Minerals & $m E q$ & $m E q / k g$ & $m E q$ & $m E q / k g$ & $m E q$ & $m E q / k g$ & $m E q$ & $m E q / k g$ & $m E q$ & $m E q / k g$ & $m E q$ & $m E q / k g$ \\
\hline $\mathrm{K}, m E q$ & 35.5 & 52.2 & 34.6 & 39.3 & 23.2 & 41.4 & 30.4 & 19.9 & 67.2 & 28.2 & 190.9 & 31.6 \\
\hline $\mathrm{Na}, m E \boldsymbol{q}$ & 50.5 & 74.2 & 25.1 & 28.5 & 48.0 & 85.7 & 105.2 & 69.0 & 249.0 & 104.6 & 477.8 & 79.2 \\
\hline $\mathrm{Ca}, m E q$ & & & & & 7.0 & 12.5 & 46.0 & 30.1 & $2,898.2$ & $1,230.0$ & & \\
\hline $\mathrm{P}$, mmoles & 37.7 & 55.3 & 38.7 & 43.9 & 10.7 & 19.1 & 19.2 & 12.6 & 864.0 & 363.0 & 970.3 & 161.0 \\
\hline
\end{tabular}

Sodium and potassium were estimated using an EEL flame photometer.

Water was estimated by difference, with the assumption that apart from protein, fat, and bone mineral, the only other solids present were soluble minerals, which were $1 \%$ of the weight of water in the tissue. This method tends to overestimate water by about $1 \%$.

Acid hydrolysis. To bring the parts into solution the method of Venn, McCance, and Widdowson (18) was used. Analytical techniques were as above except that no correction was applied for nitrogen loss during hydrolysis.

Ash was determined after heating the hydrolysate in a muffle furnace at $450^{\circ} \mathrm{C}$. Hydroxyproline in the hydrolysate was measured by the method of Neuman and Logan (19), and collagen was estimated by multiplying the hydroxyproline by 7.09. Calcium was measured by the method of McCrudden (20) and phosphate by the method of Taussky and Shorr (21).

The calcium and phosphate concentrations found in

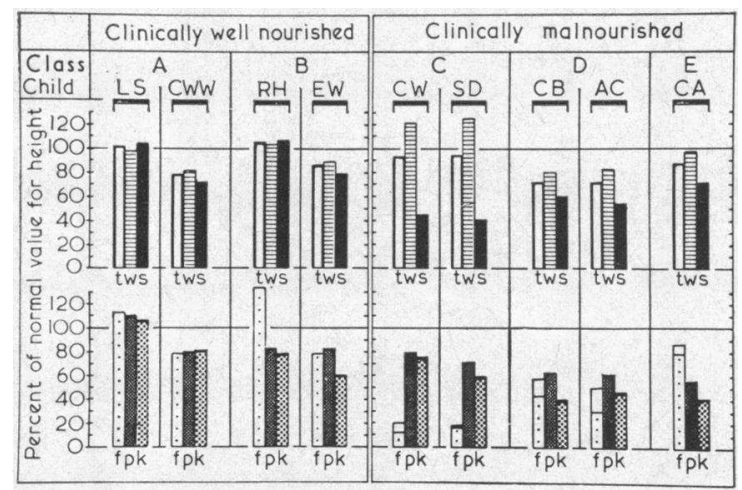

Fig. 1. Total body weight (T), water (w), solids (s), fat (F), protein (P), ANd potassium (K) AS A PERCENTAGE OF EXPECTED VALUE FOR HEIGHT. The upper unshaded part of the column representing total body fat (f) is liver fat. the brain suggested that the brain had been contaminated by bone dust when the skull was opened at post-mortem.

\section{Body composition}

Normal weight of a child about 1 year old. We have used the height of the child, rather than its age, to determine its expected weight for reasons discussed later.

Calculation of normal percentage body composition for a child about 1 year of age. The data available from the literature concerning whole body analyses of subjects at various ages are summarized in Table II. The data from subject $\mathrm{S}$ analyzed by Widdowson, McCance, and Spray (22) are not included because this 48-year-old man was "wasted and edematous," and his body composition is clearly abnormal when compared with the other data. The $4 \frac{1}{2}$-year-old boy $\mathrm{T}$ in this paper is included, although he was evidently dehydrated at the time of death, because this is the only analysis available of a subject between birth and 25 years.

Fat. In the top line of the table the fat is given as a percentage of body weight. The remaining components of body composition are given per kilogram fat-free body weight.

Protein. The protein concentration in utero increases steadily to $137 \mathrm{~g}$ per $\mathrm{kg}$ fat-free body weight at birth. The average value among the six adults is $205 \mathrm{~g}$, and the value of $238 \mathrm{~g}$ in the $4 \frac{1}{2}$-year-old child is almost certainly too high. The interpolated value of $170 \mathrm{~g}$ at 1 year is perhaps too low; if so, the protein deficits that have been found among the malnourished children in our series should be even greater.

Water. The value of $780 \mathrm{~g}$ is interpolated between the value at birth of $882 \mathrm{~g}$ and the average adult value of $724 \mathrm{~g}$ per $\mathrm{kg}$ fat-free weight. It also agrees with values found by dilution methods in living normal children.

Minerals. Fortunately the values found in utero and those found in adults fall on a fairly smooth curve when calculated on a fat-free body weight basis. The values given in the table have been interpolated by eye on these curves at 1 year. 


\section{Results}

The analyses of the eight bodies hydrolyzed in alkali are shown in Table III, and the analysis of the body hydrolyzed in acid is in Table IV. The total body potassium of C.W., S.D., and C.A. was determined on a pooled sample from each fraction, so the potassium content of the individual fractions is not known.

The difference between the weight of the body before post-mortem examination and the sum of the weights of the parts after dissection is shown as "Loss" in the first column of Tables III and IV. It is probable that the greatest part of this loss is water that evaporated from the body during dissection; however, we do not know exactly what proportion was lost from the other fractions, so no attempt has been made to make this correction to individual fractions in these tables.

In Figure 1 the total body composition has been corrected for evaporative loss, and the amount of each component measured (water, solids, fat, protein, and potassium) has been expressed as a percentage of the expected amount in a normal child of the same height. In the upper part of the figure, body weight, total body water, and, by subtraction, total body solids are shown. This information can easily be obtained in the living child. In the lower part of the figure the fat, protein, and potassium content of the child is compared with the expected values.

Total body weight is obviously not a good index of body composition. C.W.W. is a thin child, but all the components measured are reduced by about the same proportion. The most striking difference between the clinically well-nourished children and the malnourished ones is that the former generally preserve a normal proportion between the various components, whereas the latter show gross disproportion. An exception to this is R.H., who although well nourished, has an excessive amount of fat for her size.

Total body water is relatively increased in all the malnourished children. In class $\mathrm{C}$, however, the disproportion is particularly striking. These children have $121 \%$ and $125 \%$ of the water expected for their height, whereas their total solids are $46 \%$ and $41 \%$, respectively, of the expected amount. This remarkably low solid content is due largely to the very low fat content of these two children.
Total body solids, therefore, do not necessarily reflect total protein, because the children in class C contain less solids but more protein than those in class $\mathrm{D}$.

Total fat, as Moulton (23) pointed out, is the most variable component of body composition. In Figure 1 the liver fat is shown in the upper unshaded part of the first column in the lower part of the figure. In the well-nourished children liver fat was not a significant fraction of total fat, but in three of the malnourished children more than $30 \%$ of the total body fat was in the liver. There is no obvious relationship between the amount of subcutaneous fat and liver fat, nor between total fat and any other body component.

Total body protein as a percentage of the expected value is generally lower in the malnourished group than in the well nourished. However, the division is not quite clear; C.W.W. had $79 \%$ of expected protein but was clinically well nourished, and C.W., who was clinically extremely malnourished, had $80 \%$ of the expected amount of protein for her height. C.B., A.C., and C.A., however, all showed considerable protein deficit, with $63 \%, 62 \%$, and $57 \%$ of expected protein, respectively.

Total body potassium showed deviations in the same direction as total protein, but of greater magnitude. The most severely protein-deficient children, C.B., A.C., and C.A., were also the most potassium depleted. They had $41 \%, 47 \%$, and $41 \%$, respectively, of their expected potassium content. C.B. and A.C. are particularly interesting, because both had potassium supplements in the hospital before death. A.C. received $160 \mathrm{mEq}$ of $\mathrm{KCl}$ orally in the 4 days before he died, but at death his total potassium content was only $187 \mathrm{mEq}$. Unfortunately, it was not possible to measure his potassium balance in the hospital, since he was too ill to permit continuous urine collections. C.B. received only 15 $\mathrm{mEq}$ of potassium before death, and although both C.B. and A.C. died with a severe potassium deficit, there is a difference in the distribution of potassium within the body when organ contents are expressed as milliequivalents $\mathrm{K}$ per kilogram fat-free weight. The figures for C.B. are brain 37 , liver 56 , and body 26 , whereas for A.C. they are brain 55, liver 70 , and body 27 . In both cases the brain and body potassium is low, 
but in A.C. the liver potassium concentration is normal and the brain potassium is more nearly normal.

Sodium, calcium, and phosphate. Eight of the nine children were hydrolyzed in sodium hydroxide, so no figures are available for the tissue contents of the above minerals. However, in the case of A.C., one of the children with kwashiorkor, hydrochloric acid was used, and the sodium, calcium, and phosphorus contents of the various fractions are shown in Table IV. As might be expected, the sodium concentration is high compared with the potassium. Thus while on a fatfree basis this child contained only $61 \%$ of the expected potassium concentration, his sodium concentration was $93 \%$ of the expected, and calcium and phosphorus were $77 \%$ and $79 \%$, respectively.

Collagen. Child A.C. was the only one in whom hydroxyproline was measured. From this value the total collagen can be calculated, and the results are shown in Table IV. Unfortunately, this measurement was not made in any of the well-nourished children, and there is not enough published information to enable us to say if the collagen content of A.C. was normal or not (24).

Bone mineral is shown in Table III. There is no evidence that the malnourished children had less bone mineral per kilogram of observed body weight than the well nourished. However, they had somewhat less bone mineral per centimeter of height.

\section{Discussion}

The reasons for using the height rather than the age to determine the expected weight of a child are as follows : 1) Height is easier to determine accurately than age. 2) It has been found clinically that a deficit of weight for height is a more accurate guide to prognosis than weight for age. This is probably because a child who has been moderately malnourished over a long period has a better prognosis than one who was initially well fed and then severely malnourished. If both children reach the same weight for age, the former child will have a greater weight for height. 3) A child, for genetic or endocrine reasons, may have a small stature but a normal body composition. A well-nourished dwarf has an ab- normally low weight for age, but a normal weight for height.

It is obviously dangerous to attempt to generalize about the effect of infantile malnutrition on body composition on the evidence of only nine whole body analyses. However, these analyses do show clearly some of the changes that may occur.

None of the children analyzed was nutritionally completely normal. However, L.S. corresponded closely, both clinically and chemically, to the predicted normal body composition for a child of his height. C.W.W. demonstrates that a child who is clinically well nourished may have normal proportions of all body constituents although underweight for her height. R.H. and E.W. were both nutritionally abnormal at the time of death, although they did not show clinical signs of malnutrition. It may be that the generous supply of fat in R.H. helped to conceal from the clinician her loss of protein and potassium. R.H. and C.A., the two children who probably suffered a rapid terminal loss of protein, were the two in whom liver protein was the smallest fraction of total body protein. This observation fits well with the findings of Addis, Poo, and Lew (25) concerning the effect of brief starvation on rats. E.W. at the time of death was also moderately malnourished, but had reached this state much more gradually than R.H.

Among the children who died of clinical malnutrition C.W. and S.D. are similar in that both had been malnourished for half of their life, whereas the other three children suffered more acute malnutrition. As a result of their more chronic course, C.W. and S.D. were more stunted in growth than the others, and they both had greatly increased body water and greatly diminished fat, which combined to produce clinically very obvious edema. C.B. and A.C. were similar in having very fatty livers, decreased protein, and greatly decreased potassium. C.A. resembled them but had the additional complication of proteinuria.

Our data show that a malnourished child is protein depleted as Waterlow (2) suggested, if a normal child of the same height is a valid standard for comparison. On this basis our children with kwashiorkor are depleted to less than twothirds of their expected protein. A normal adult dog that is put on a protein-free, but otherwise 
adequate, diet will die when he has lost about onethird of this total body protein (26).

In our series the malnourished child is always overhydrated with respect to his other body components. In the chronically malnourished child with gross loss of fat the total water may be $20 \%$ more than the amount expected for a normal child of the same height. In the more acutely malnourished child, however, the water excess is only relative, since the absolute amount of water found is less than would be expected.

Potassium depletion is a constant finding in malnourished children and may be very severe indeed. Very low concentrations of potassium in the brain were found in some children who died in coma. There is some evidence that potassium supplementations replenish the liver and probably the other viscera more rapidly than the skeletal muscle.

Wallace (27) has drawn attention to the constancy of the composition of the fat-free body in animals under varying dietary conditions and says, "It is difficult to escape the conclusion that the significance of the constancy in animals also applies to the human species." It is evident from our data that the fat-free body of severely malnourished children may show wide variations in composition, and no constant relationship between any two components can be assumed.

\section{Summary}

A post-mortem analysis has been made of five severely malnourished and four relatively wellnourished children between the ages of 6 and 16 months. The percentage composition of a normal child of 1 year has been calculated by interpolation between published whole body analyses. Reasons are given for using the height rather than the age of a child to calculate its expected weight. The total amount of fat, protein, water, and potassium in the body and in certain organs of the children analyzed has been compared with the expected amount for a normal child of the same height.

Two children with marasmic kwashiorkor had the following percentages of the expected amounts of fat, water, protein, and potassium: fat 22 and $18 \%$, water 121 and $125 \%$, protein 80 and $72 \%$, and potassium 76 and $61 \%$ Two children with kwashiorkor had the following percentages of the expected amount: fat 58 and $50 \%$, water 81 and $82 \%$, protein 63 and $62 \%$, and potassium 41 and $47 \%$.

Liver fat may be a significant fraction of total body fat; in the cases analyzed it ranged from $0.4 \%$ to $39.6 \%$ of total fat. There is no obvious relationship between the amounts of liver fat and subcutaneous fat.

In contrast to the findings in animal experiments, the composition of the fat-free body of the children studied showed wide variations. It is not possible to predict accurately total protein in the severely malnourished child from body weight, total body water, total body potassium, skinfold measurement of fat, or any combination of these four measurements.

Total protein is severely reduced in malnourished children, but it is probably the nature, distribution, and concentration of the protein that is left, rather than its absolute amount, which determines the clinical outcome.

\section{Appendix}

\section{Summaries of case histories of cases analyzed}

L.S. He was admitted to the hospital with marasmus at the age of 8 months weighing $3.16 \mathrm{~kg}$. After $6 \frac{1}{2}$ weeks on the ward diet, which supplied approximately $150 \mathrm{cal}$ and $4 \mathrm{~g}$ protein per $\mathrm{kg}$ body weight per day, he was discharged weighing $5.53 \mathrm{~kg}$ and clinically well. $\mathrm{He}$ died suddenly at home 12 days later, having lost $700 \mathrm{~g}$ since discharge. At post-mortem examination he had pneumonitis and septic necrosis of some splenic follicles. His death was probably due to virus pneumonia.

C.W.W. This girl was premature; her birth weight was $1.6 \mathrm{~kg}$ after 7 months gestation. She came to the hospital at age 13 months with marasmic kwashiorkor, weighing $3.4 \mathrm{~kg}$. After 5 weeks on the ward diet she weighed $4.7 \mathrm{~kg}$. During her sixth week in the hospital she caught measles, developed bronchopneumonia, and died suddenly. Death was attributed to bronchopneumonia.

R.H. This girl's birth weight was $4.3 \mathrm{~kg}$; she was breast fed for only 2 weeks, but apparently given adequate quantities of cow's milk on weaning. She came to the hospital at age 9 months, severely ill with gastroenteritis. At post-mortem examination the left middle ear contained pus, there was lymphoid hyperplasia in the intestines, severe fatty change in the liver, and a marked polymorphonuclear interstitial response in the pancreas.

$E . W$. This girl's exact age and birth weight are unknown. Her foster mother brought her to the hospital at the age of 7 months when she weighed $3.74 \mathrm{~kg}$ and 
was marasmic. She responded well to a ward diet and was discharged after $6 \frac{1}{2}$ weeks weighing $5.52 \mathrm{~kg}$. She continued to improve as an outpatient and reached $9 \mathrm{~kg}$ at the age of 12 months. However, she then developed a series of respiratory infections and recurrent tonsillitis and lost weight steadily. At the age of 13 months she choked after a meal and died. Post-mortem examination suggested that death was due to inhalation of vomit.

$C . W$. This girl was weaned at 2 months of age and thereafter was given no fresh or powdered milk, and her condition deteriorated rapidly. She had repeated attacks of gastroenteritis and was brought to the hospital at the age of 6 months, grossly malnourished, with edema, enlarged liver, and dyspigmentation of skin and hair. She was anemic (hemoglobin, $5.4 \mathrm{~g}$ per $100 \mathrm{ml}$ ) and was given a transfusion of $200 \mathrm{ml}$ blood. She was maintained on intravenous fluids, but her condition never improved and after a week she died. At post-mortem examination she was found to have pulmonary edema, atelectasis and hemorrhage, and adrenal hemorrhages. Death was attributed to malnutrition.

S.D. This girl was weaned at the age of 4 months onto a diet consisting mainly of one-third of a pound of milk powder per week. She was given no solid food. She had been ill since she was 10 months old and at 16 months was brought to the hospital grossly malnourished, with generalized edema, angular stomatitis, dyspigmentation of skin and hair, gastroenteritis, and clinical signs of bronchopneumonia, but with no enlargement of the liver. She was anemic (hemoglobin, $3.2 \mathrm{~g}$ per $100 \mathrm{ml}$ ) and was given $200 \mathrm{ml}$ of blood intravenously and antibiotics, but did not respond. She continued to have diarrhea and was hydrated intravenously. She died after one week in the hospital. At post-mortem examination she was found to have acute bronchopneumonia, probably of virus origin, and cerebral edema in addition to the clinical signs already described.

C.B. This girl was brought to the hospital at the age of 14 months. She had been weaned at 5 months onto a fairly good diet, but since the age of 10 months she had not been thriving. On admission she weighed $5.71 \mathrm{~kg}$, had moderate edema, dyspigmentation of skin and hair, and was jaundiced. Her liver was palpable $7 \mathrm{~cm}$ below the right costal margin. She looked very ill and was stuporous. She was given antibiotics and clear fluids containing $12 \mathrm{mEq}$ of potassium per day, but her stupor deepened and she died the day after admission. At post-mortem examination she was found to have a moderate bronchopneumonia and a grossly enlarged fatty liver. Death was attributed to malnutrition with bronchopneumonia as a contributing cause.

A.C. This boy was breast fed for 7 months. At the age of 12 months he came to the hospital in a grossly malnourished condition. He had been having diarrhea and vomiting for the previous 3 months, and on admission he weighed $6.3 \mathrm{~kg}$, had moderate edema, angular stomatitis, dyspigmentation of skin and hair, and infected ulcers around his ears and in his groin. His liver edge was $9.5 \mathrm{~cm}$ below the right costal margin and he was jaundiced. $\mathrm{He}$ was given $7 \mathrm{mEq}$ of potassium with each feeding every 4 hours, so when he died on his fifth day in the hospital he had received $160 \mathrm{mEq}$ of potassium. At post-mortem examination the only significant findings were an enormous fatty liver and two abscesses in the lung, each about $3 \mathrm{~mm}$ in diameter. Death was attributed to malnutrition with liver failure.

C.A. This boy was well nourished up to the age of 6 months. He was brought to the hospital very ill at the age of 11 months. He was then grossly edematous and had a large fatty liver, but his skin and hair were normal, and it appeared unlikely that his edema was due to malnutrition alone. $\mathrm{He}$ was admitted to the hospital but died before any treatment could be given. At post-mortem examination the large, fatty vacuoles in the liver and marked atrophy of the pancreas indicated that he had been malnourished for some months, but in his kidneys there was extensive recent tubular damage and fluid containing protein in the tubular lumen and capsular space. In addition there was a bronchiolitis and a left acute otitis media. The sequence of events leading to death was probably malnutrition of some duration, on which had been superimposed an infection in the lung and middle ear, and finally, probably only 2 or 3 days before death, damage to his kidneys causing proteinuria. It is possible that the kidney damage arose from some inappropriate medicine that was given in good faith, but the result was a sudden loss of protein from a child who was already malnourished.

\section{Acknowledgments}

We are grateful to Professor D. A. N. Hoyte of the Department of Anatomy, University of the West Indies, who enabled us to obtain the material for these analyses, and Dr. W. B. Robertson and the staff of the Department of Pathology, University of the West Indies, for conducting the post-mortem examinations.

\section{References}

1. Jelliffe, D. B., G. Bras, and K. L. Stuart. Kwashiorkor and marasmus in Jamaican infants. W. Indian med. J. 1954, 3, 43.

2. Waterlow, J. C. In Protein Malnutrition, Proceedings of a Conference in Jamaica, 1953, J. C. Waterlow, Ed. Rome, F.A.O., 1955, p. 5.

3. Waterlow, J. C. The protein content of liver and muscle as a measure of protein deficiency in human subjects. W. Indian med J. 1956, 5, 167.

4. Waterlow, J. C., and C. B. Mendes. Composition of muscle in malnourished human infants. Nature (Lond.) 1957, 180, 1361.

5. Frenk, S., J. Metcoff, R. Gómez, R. Ramos-Galván, J. Cravioto, and I. Antonowicz. Intracellular composition and homeostatic mechanisms in severe chronic infantile malnutrition. Pediatrics 1957, 20, 105.

6. Smith, R. Total body water in malnourished infants. Clin. Sci. 1960, 19, 275. 
7. Smith, R., and J. C. Waterlow. Total exchangeable potassium in infantile malnutrition. Lancet 1960, $1,147$.

8. Mendes, C. B., and J. C. Waterlow. The effect of a low protein diet, and of refeeding, on the composition of liver and muscle in the weanling rat. Brit. J. Nutr. 1958, 12, 74.

9. Cabak, V., J. W. T. Dickerson, and E. M. Widdowson. Response of young rats to deprivation of protein or of calories. Brit. J. Nutr. 1963, 17, 601.

10. Widdowson, E. M., and R. A. McCance. Effect of a low-protein diet on the chemical composition of the bodies and tissues of young rats. Brit. J. Nutr. 1957, 11, 198.

11. Elkinton, J. R., and E. M. Widdowson. Effect of chronic undernutrition on body composition in the rat. Metabolism 1959, 8, 404.

12. Widdowson, E. M., and R. A. McCance. The effects of chronic undernutrition and of total starvation on growing and adult rats. Brit. J. Nutr. 1956, $10,363$.

13. Wallace, W. M., W. B. Weil, and A. Taylor. The effect of variable protein and mineral intake upon the body composition of the growing animal. Amer. Pediat. Soc., May 9-11, 1956, Buck Hill Falls, Pa.

14. Widdowson, E. M., J. W. T. Dickerson, and R. A. McCance. Severe undernutrition in growing and adult animals. Brit. J. Nutr. 1960, 14, 457.

15. Waterlow, J. C., J. Cravioto, and J. M. L. Stephen. Protein malnutrition in man in Advances in Protein Chemistry. 1960, vol. 15, p. 163.

16. Nelson, W. E. Textbook of Pediatrics, 7th ed. Philadelphia, W. B. Saunders, 1959, p. 50.
17. Garrow, J. S., and K. Fletcher. The total weight of mineral in the human infant. Brit. J. Nutr. 1964, 18, 409.

18. Venn, J. A. J., R. A. McCance, and E. M. Widdowson. Iron metabolism in piglet anaemia. J. comp. Path. 1947, 57, 314.

19. Neuman, R. E., and M. A. Logan. The determination of hydroxyproline. J. biol. Chem. 1950, 184, 299.

20. McCrudden, F. H. The determination of calcium in the presence of magnesium and phosphates: the determination of calcium in urine. J. biol. Chem. 1911, 10, 187.

21. Taussky, H. H., and E. Shorr. A microcolorimetric method for the determination of inorganic phosphorus. J. biol. Chem. 1953, 202, 675.

22. Widdowson, E. M., R. A. McCance, and C. M. Spray. The chemical composition of the human body. Clin. Sci. 1951, 10, 113.

23. Moulton, C. R. Age and chemical development in mammals. J. biol. Chem. 1923, 57, 79.

24. Widdowson, E. M., and J. W. T. Dickerson. The effect of growth and function on the chemical composition of soft tissues. Biochem. J. 1960, 77, 30.

25. Addis, T., L. J. Poo, and W. Lew. The quantities of protein lost by the various organs and tissues of the body during a fast. J. biol. Chem. 1936, 115, 111.

26. Garrow, J. S. The effect of protein depletion on the distribution of protein synthesis in the dog. J. clin. Invest. 1959, 38, 1241.

27. Wallace, W. M. Nitrogen content of the body and its relation to retention and loss of nitrogen. Fed. Proc. 1959, 18, 1125. 